The Quarterly Journal of Austrian Economics

Volume 23 | NO. 3-4 | 390-426 | FALL/Winter 2020 WWW.QJAE.ORG

\title{
Autarkic Entrepreneurship
}

\author{
Mark D. PACKARD*
}

JEL Classification: B53, L26, D10, D13

Aвstract: The socalled autistic economy (here autarkic) - the economy of one-has been employed by Austrian theorists as a useful analytic baseline on which to build catallactic (market process) theory, which has included a theory of entrepreneurship. But so far, the autarkic economy has been examined almost exclusively in this way. In this article it is argued that the autarkic economy must brought forward in our theorizing to be understood not as a mere analytic tool, but as a real and significant aspect of praxeology. It is proposed that catallaxy and autarky be understood as substitutes, complements, and even competitors. Extending Austrian theorizing of the autarkic economy, the entrepreneurial function within autarkic economies is examined and elaborated. It is shown that, far from only a catallactic role, the entrepreneurial function is prominent within the autarkic economy also, in which the entrepreneur plays a significant role in augmenting individual lifestyles and, thus, total economic development.

\section{INTRODUCTION}

Tn the 2000 film Cast Away, character Chuck Noland (Tom Hanks) found himself stranded alone on an uninhabited island with an extremely limited number of resources and tools for his survival. A systems engineer for a shipping corporation, Noland also possessed

\footnotetext{
*Mark Packard (mpackard@unr.edu) is Assistant Professor of Management at the University of Nevada, Reno. The author thanks Professor Per Bylund and the anonymous reviewers for their thoughtful guidance and feedback on an earlier draft. 
limited knowledge and experience relevant to his newfound circumstances. With the familiar knowledge that rubbing sticks together could produce fire, he set himself to the task to little avail. In near desperation, Noland accidentally split one of the pieces of wood. Giving the split piece of wood another try, the kindling began to smoke. Realizing that the split piece of wood afforded the kindling additional access to air, he innovatively increased that access by sweeping an air canal in the sand beneath the kindling and by inserting a small object into the split wood to keep it open. Putting himself again to the task, he finally ignited the kindling and produced a fire. Elated, he exclaimed, "Look what I have created!"

The question this article seeks to answer is this: Was Noland an entrepreneur?

Austrian school economists, beginning with Carl Menger, have started their economic theorizing from the perspective of the "autistic" or "autarkic"1 economy (Mises 1998, 244), the singleperson "isolated household economy" (Menger 2007, 75), ${ }^{2}$ the "Crusoe economy" (Rothbard 2009, 319), the economy of one. It seems strange to the modern economist to suppose a single person to be an "economy"; but it is, in fact, the mainstream economist's difficulty in grasping this fundamental reality that has impeded a much deeper analysis and understanding of economic processes. After all, a single actor produces and consumes, demands and supplies, values, innovates, and economizes. If economics cannot explain a single actor's economizing of their own scarce resources within the bounded scope of their own life and property, it cannot succeed in explaining human action more broadly.

\footnotetext{
$\overline{{ }^{1} \text { Mises (1998) uses both terms - autistic and autarkic - in similar fashion but formally }}$ adopts autistic to reference the economy of one and autarky to reference political self-governance. However, modern idiom has laden the term autistic with the burden of a human development disorder. To avoid potential confusion (see, e.g., Devine 2006), I have elected to employ autarkic in the place of autistic.

${ }^{2}$ I should here clarify that whether an "isolated household economy" (Menger 2007, 75) is autarkic or catallactic hinges on whether there is interpersonal exchange of produced goods. Thus, if there is a single producer in the household, there is no market and the household is "at the disposal of a single economizing individual," i.e., autarkic. If there are multiple producers in the household, however, interpersonal exchange and a division of labor between producers can emerge, whether prices of some form are used or not, in which case it is catallactic.
} 
Of course, microeconomies, such as households, are not an insignificant aspect of current economic theorizing. Family and household economics have been developed by, e.g., Gary S. Becker (1965, 1991), Robert A. Pollak (1985), Theodore W. Schultz (1975), Kelvin Lancaster (1975), and many others since. But at this microscopic level, although the supply side is admitted as an input into the market's circular flow, attention has been arrested almost wholly on the demand side, exploring the economics of how individuals and households determine what to demand (e.g., Michael and Becker 1973), which can then be aggregated into utility functions for macroeconomists. Thus, microeconomics has come to be dominated by behavioral economics and its consumer behavior theories, while "Crusoe economics" has come to be largely dismissed and ridiculed.

Even within the Austrian school autarkic praxeology has remained vastly underdeveloped, so far employed primarily as a building block toward understanding catallactic processes. Thus, even Austrian theory has neglected (but not altogether ignored) a vast and vital aspect of the overall economy - the extensive autarkic or do-it-yourself (DIY) economies that we each embody.

This research has two main functions. First, it advances an argument that autarkic economies are not at all inconsequential, but ought to be brought to the fore of Austrian theorizing. This piece of the praxeological puzzle places the autarkic economy as a real and direct competitor, or sometimes complementor, of the catallactic economy. In short, DIY is a real and common substitute for satisfactions purchased in catallactic markets. By focusing myopically on catallactic exchange, we overlook a critical option within a vast majority of consumer choice sets.

Its second function is to advance Austrian theorizing on autarkic economics by introducing and elaborating the concept of autarkic entrepreneurship. Although Austrian theorists have, again, focused almost exclusively on the catallactic function of the entrepreneur (e.g. Kirzner 1973; Lachmann 1986; Mises 1998), there is nothing about the entrepreneurial function per se that conscribes it to catallaxy alone. Instead, it is shown that the entrepreneurial function is very much alive and well within the autarkic economy also. To make a compelling case, it is necessary to first carefully examine and elaborate 
the essence of entrepreneurship, as this essence has been the source of some disagreement among Austrian theorists (and others).

\section{AUTARKIC ECONOMICS}

So-called Crusoe economics_- "that much maligned but highly useful analysis that sets individual man starkly against Nature and analyzes his resulting actions" (Rothbard 2009, lvi)—is the backbone of Austrian theorizing. As Ludwig von Mises (1998, 244) put it, "economics cannot do without it." Both Mises and Murray $\mathrm{N}$. Rothbard in their seminal treatises precede their analysis of interpersonal or catallactic exchange with a baseline theory of the "autistic economy," a foundational foil in which interpersonal or catallactic exchange is absent, without which we could not see what catallactics would add, specifically, to the analysis. That is, to see why we voluntarily form and interact in a market, it is first necessary to understand how one economizes without one. However, this largely neglected aspect of economic theory is far more interesting and important than we have so far admitted.

\section{Autarkic Exchange}

Economic action is comprised of two types of exchanges: catallactic and autarkic. Catallactic exchange references the traditional market exchange, which is the centerpiece of modern economic theory. However, it is not the only type of economic exchange. "Autistic [or autarkic] exchange consists of any exchange that does not involve some form of interpersonal exchange of services" (Rothbard 2009, 84). But how can one exchange except with another?

A satisfactory answer to this is found in the deeper analysis of economic action that Mises evokes: "Action always is essentially the exchange of one state of affairs for another state of affairs. If the action is performed by an individual without any reference to cooperation with other individuals, we may call it autistic [or autarkic] exchange" (Mises 1998, 195). In other words, life, even in social isolation, is comprised of endless tradeoffs, which, in a strict economic sense, can and, perhaps, should be theoretically described as an exchange. By cooking one's dinner, one exchanges time, labor, and raw foodstuffs 
for a warm meal—one no longer has those resources available, which could have plausibly been used for other productive ends. However, the hot, homecooked meal is valued over whatever alternative uses one might find for that time, labor, and those foodstuffs and, thus, one choses to make the exchange.

But with whom is one trading in such an exchange? There is no clear answer to this. We might say that one is trading with oneself, or with no one, or perhaps "with nature" (Kirzner 1973, 37). Nothing is being given to anyone-yet there is an exchange made, scarce resources for consumable goods and services. Thus, the principle of "opportunity cost" extends to the autarkic economy, for there is an opportunity cost that is sold in exchange for any chosen action.

The implication of this is that much of the economy is autarkic, individuals acting for themselves. If you were to break down your day into autarkic and catallactic actions (exchanges), it should be little surprise that a significant part of each day is comprised of autarkic exchanges, which can include rest and sleep, personal hygiene, eating, certain entertainment options, and so forth. The autarkic economy is not just a useful analytical foil but is a real and significant part of the human experience.

\section{The Autarkic Economy}

When you are ready for a meal, does your mind instantly wander to those restaurants available to you that might provide you with a prepared meal? When your teeth feel dirty, do you call your hygienist? Do you employ a housecleaning service to pick up after you and make your bed each day?

A significant amount of economic value we facilitate for ourselves rather than satisfying those unmet needs and the sense of "uneasiness" through catallactic market exchange. It is true that sometimes we like to dine out, to get our teeth professionally cleaned, or to our have our homes tidied up by hired hands. But far more often we perform these tasks for ourselves.

This raises a question: If we do such tasks ourselves, what happens to the economic value that the professionals did not capture from us? Is such value lost because we were unwilling to pony up our savings in support of the local economy? The answer is, of course, that we 
capture such economic value ourselves-the benefit of the service, i.e., the economic value, is obtained while the cost of obtaining it is retained, largely, by the do-it-yourselfer, leaving those costs available for the pursuit of other ends. In other words, the do-it-yourselfer participates not in catallactic exchange, but in autarkic exchange. In terms of a simple utility function, the expected utility, all costs and benefits accounted for, is in many cases greater in the autarkic economy than in the catallactic economy. It is often better overall (e.g., cheaper, more rewarding) to do it yourself than to pay another to do it.

Contrast such cases with, for example, the value provided by a medical surgeon. While it is true that self-diagnosis has become easier than ever with the vast amount of medical information that we now have access to online, few of us would perform anything more than a minor toenail surgery on ourselves. Many market needs are too complex, involved, or require significant expert training that do-ityourself amateurs do not have and, thus, cannot do for themselves, at least not without some additional capital goods. One cannot massage one's own back without the use of some additional capital goods that would allow me to reach those tight muscles. Leonard Read's (1958) famous essay "I Pencil" illustrates the limitations of autarkic production well. The autarkic economy alone simply cannot provide economic goods even as simple as a pencil due to their complexity and the total knowledge, skill, and capital required.

Thus, at one end of the spectrum, we have certain services that, in fact, cannot be performed by catallactic markets. For example, the spiritual needs and values that many economic actors pursue through, e.g., churchgoing cannot be contracted out, the benefits pursued accruing only to those who go and do for themselves. Similarly, while we have, in recent decades, found new ways to socially connect people, such connections, including love, must always be made by those persons themselves, and cannot be purchased from or contracted out to others.

At the other end of the spectrum, we have some services that absolutely cannot be performed autarkically. At this extreme end we are talking about literal impossibilities. One cannot, for example, both perform a play and enjoy it live from the gallery at the same time. Close to that end of the spectrum would be those goods and services that, although not literally impossible to perform for one's 
self, are far too complex for a single actor, such that it is effectively impossible (e.g., computer manufacturing).

Many economic goods and, especially, services, however, lie somewhere between these extremes, where the economic actor has a real choice whether to do it (or make it for) themself or else pay someone else to do it. In these circumstances, the value of doing it yourself (e.g., cost savings) is counterbalanced by other considerations, such as the quality of work. Although it seems silly to even think of a catallactic market for some services, such as showering or getting dressed in the morning, these services could be contracted out (if, for example, physical ailments made such activities impossible to do one's self). However, these services we prefer to do ourselves (if we can), because the cost of doing so is low, whereas the cost of contracting on the market for such services would likely be quite high. You can hire a chauffeur, but such is a luxury for the very wealthy, whereas it is not excessively costly to drive yourself. Conversely, a great many goods and services could be done autarkically, but the costs of doing so are prohibitively high, while the cost of hiring them out is quite low-you can buy a pencil for under ten cents.

The most interesting examples, however, are far more moderate. If a homeowner decided to repaint a room, she would be faced with a decision of whether it is worth hiring professional painters, who would save her the time and likely do a higher-quality job, or else save hundreds of dollars doing the job herself. Such decisions, which most of us regularly face, illustrate a key insight: that the autarkic and catallactic economies are often competitors. A restaurant is in competition with other restaurants, certainly. But it is also competing against your kitchen and recipe book-the uneasiness (i.e., hunger pangs) that we look to satisfy by going to a restaurant can also be satisfied ourselves if we decide that our own efforts in doing so are worth the advantages. There are a great many goods and services that are comparable, in terms of cost and benefit, between the autarkic and the catallactic economies.

Not all autarkic activities are competing with catallactic markets, however. In many cases they are complements, together combining to augment total achieved value. For example, while we generally like to wash ourselves, we generally use market products (e.g., shampoo) to do so. In fact, it is interesting to observe that catallactic 
markets have arisen as supports to the autarkic or DIY economy, such as home improvement stores and DIY instructional platforms.

Economic analysis that fails to account for the very real and productive autarkic economy is incomplete. A business strategist that focuses myopically on industry competition may be severely unprepared when consumers turn away from that industry completely to perform the needed services themselves. For example, the tax accountancy industry has greatly suffered as online tax preparation software has enabled people to prepare and file taxes cheaply and easily themselves. Home kitchen technologies (such as bread makers, sous vide machines, and pressure cookers) have made preparing high-quality homecooked meals much easier and accessible to the culinarily untrained. Entertainment options not only include productions by entertainers but also autarkic options such as social gatherings, afternoon strolls, family game nights, and quiet evenings enjoying the starlight on the porch.

By theoretically elaborating the autarkic economy, we gain a much more complete picture of economic phenomena, including economic growth and change.

\section{Fundamentals of the Autarkic Economy}

Before advancing the question of entrepreneurship within the autarkic economy, let us first lay some additional groundwork. How are we to define and understand this DIY economy? The fundamentals here are essentially equivalent to those laid out by Menger (2007), Mises (1998), and Rothbard (2009). But let us be explicit.

The first and most fundamental construct is subjective value. "Value is...the importance that individual goods or quantities of goods attain for us because we are conscious of being dependent on command of them for the satisfaction of our needs" (Menger 2007, 115). In other words, subjective value is not something that a thing has but is something an individual actor does-things do not have value, rather we value things. Because of this, value is individual and can be very different for different persons. Subjective value is, in fact, a wholly autarkic construct and not a catallactic constructthere is no interpersonal value. Although individual values may shift when embedded within social groups, Austrian methodological 
individualism demands that we still understand such valuations individually, and not as the brainchild of some "real" collective.

We have already seen that exchange is both an autarkic and catallactic construct. Because of this, we can also integrate the concept of price in the Mengerian sense- "the quantities of goods actually exchanged" (Menger 2007, 191) —as well as the opportunity cost (i.e., "the next best alternative forgone" [Rothbard 2009, 266]) into the autarkic economy. These costs are what is sacrificed in order to attain the valued benefit. Autarkic exchange, however, has no need of a "medium of exchange" or a "money" (Mises 1912), which is confined to catallactic exchange.

Let us also define economy for the purpose of this discussion. While it is rarely, if ever, explicitly defined, it becomes clear in the classical Austrian works that 'economy' represents the productive pursuit of need satisfactions through purposeful action. Thus, the underlying driver of economy is unmet human needs:

An imperfect satisfaction of needs leads to the stunting of our nature. Failure to satisfy them brings about our destruction. But to satisfy our needs is to live and prosper. Thus the attempt to provide for the satisfaction of our needs is synonymous with the attempt to provide for our lives and well-being. It is the most important of all human endeavors, since it is the prerequisite and foundation of all others. (Menger 2007, 77)

The mechanism of economy, the response to unmet needs, is purposeful human action (Mises 1998; Rothbard 2009). In fact, all economic action is purposeful (Mises distinguishes action from animalistic instinct and impulse), being universally pointed at the satisfaction of unmet needs. Let us, thus, define economy here as the productive actions taken toward the satisfaction of human needs.

Economic profit, then, refers to "the increase in satisfaction (decrease in uneasiness) brought about" through exchange (autarkic or catallactic), "the difference between the higher value attached to the result attained and the lower value attached to the sacrifices made for its attainment" (Mises 1998, 286). An economic loss is, then, a "a decrease in satisfaction" (Mises 1998, 287), where that which is sacrificed surpasses that which is gained in return. Thus, both economic profit and loss are always "psychic phenomena" (Mises 1998, 287; emphasis added), wholly subjective. 
Economic growth and decline, finally, refer to the overall satisfaction of human needs, in the aggregate, throughout the economy (as conscribed by the delimiters of the described economy, e.g., individual, household, local, national, global), whether it is increasing or decreasing, respectively, by average economic profits exceeding losses or vice versa. An autarkic economy grows, then, when an individual actor's overall wellbeing is increased, when his needs are more fully met by those resources at his disposal.

\section{Delineating the Autarkic and Catallactic Economies}

Let us, now, draw clear theoretical boundaries between the autarkic and catallactic economies. The definitional boundary is clear-an economy is autarkic inasmuch as it involves no interpersonal exchange and is catallactic otherwise. But let us expound briefly on the theoretical underpinnings between autarkic versus catallactic action, i.e., when and why one might be preferable to the other. These mechanisms involve, as previously implied, the personal nature of the uneasiness needing satisfaction, the complexity of the satisfaction desired, and the costs of bringing the satisfaction about (see figure 1).

\section{Figure 1. Catallactic versus Autarkic Economizing}

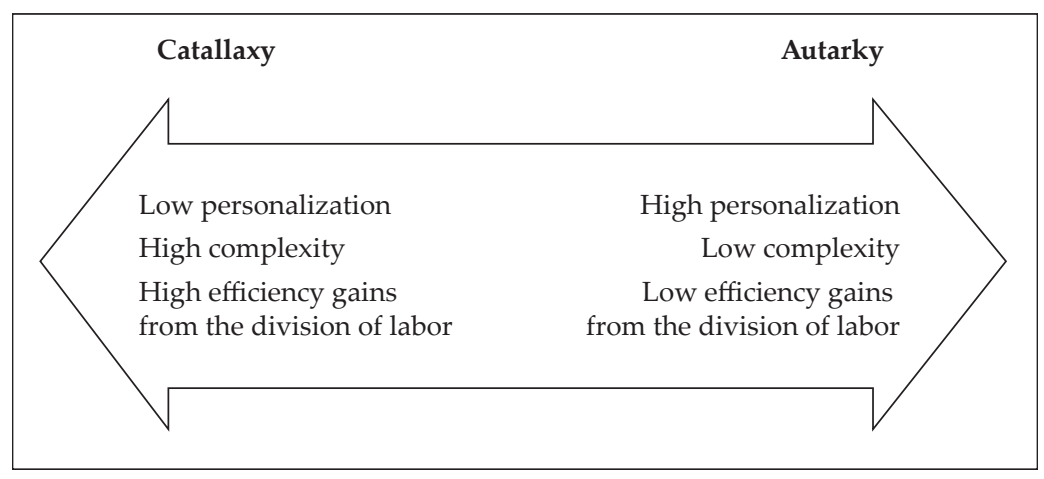

First, some human needs are innately personal in nature and, thus, must be satisfied for one's self. These generally comprise the psychological and spiritual needs - whatever they may be - of human 
existence. Per self-determination theory (Deci 1980; Deci and Ryan 2000), basic human psychological needs include autonomy, social relatedness, and competence. Satisfaction of each of these must be achieved for one's self-they cannot be purchased from others, though catallactic services and solutions might help individuals to achieve them. What might be called spiritual needs, such as hope (O'Hara 2011), are similarly personal in nature. In contrast, physiological needs, such as food, water, shelter, medicines, etc., are comparatively universal and can easily be obtained via catallactic exchange. Also, some psychological and perhaps even spiritual needs, such as need for excitement (Scitovsky 1981), may be sufficiently generic to allow satisfaction to be purchased through catallactic exchange.

A second factor in determining whether satisfactions are pursued via autarkic or catallactic economy is the complexity of the satisfaction. As the pursuit of satisfaction evolves toward more complete and, thus, more complex solutions, the complexity of such satisfaction grows beyond the capacity of a single actor and requires the cooperative productive efforts of multiple actors. For example, most market services, such as housecleaning, car repair, and cooking are doable by knowledgeable consumers because they require only a moderate amount of human capital. In contrast, most manufacturing and production requires far more human capital than a single person can possess, requiring multiple actors to act cooperatively. It is this problem that underpins Bylund's (2016) thesis that firms arise out of a need to overcome a specialization deadlock, which arises out of the fact that complex consumer satisfactions require a greater division of labor. Because such specialization is dissuaded by market pressures, entrepreneurs must contractually guarantee salary to market actors to overcome the propensity toward generic human capital and motivate their investment in the needed specialization for complex production. In other words, as solutions become more complex, catallactic markets and, specifically, firms are needed for their efficient production.

Relatedly, the boundary between the autarkic and catallactic economies lies in differences in their efficiencies due to the division of labor. In the evolution of the catallactic economy, some solutions have become so efficiently produced through specialization that it is simply much more economically efficient to purchase those solutions from specialists rather than to produce those satisfactions 
for one's self. For example, although it is still possible for one to make one's own clothing, soap, or quilt, the efforts to do so are now far costlier than to simply purchase those goods on the market. Although some still enjoy sewing, soapmaking, and quilting as hobbies, for most the catallactic economy clearly outperforms the autarkic economy for such production. In contrast, other satisfactions, such as meal preparation and various home improvement efforts, are still often cheaper to do for one's self. Thus, inasmuch as a division of labor can decrease total costs, the preference between autarky and catallaxy shifts toward the catallactic side.

\section{THE ENTREPRENEURIAL FUNCTION}

Before we can begin our exploration of the entrepreneur function within the autarkic economy, we first need to carefully define what this entrepreneurial function is. This question, of course, has been a source of some debate among economists, including Austrians. In fact, the modern academic discipline of entrepreneurship has been in active debate over the nature and foundations of entrepreneurship for over three decades now, to no imminent conclusion (see, e.g., Gartner 1988; Ramoglou, Gartner, and Tsang 2020).

\section{Prevailing Definitions of Entrepreneurship}

The nature of entrepreneurship has been examined from several angles already. Peter G. Klein (2008) classifies these various approaches to entrepreneurship into three distinct categories: occupational, structural, and functional. The first two, occupational and structural, pertain to economic realism or positivism as prevails in the economic mainstream, supposing entrepreneurship to be a thing that exists in the economy. The latter category, functional approaches, is characteristic of and to the Austrian school, depicting entrepreneurship as something that economic actors do within the economy.

\section{Neoclassical Economics}

Early entrepreneurship research in mainstream (primarily neoclassical) economics depicted entrepreneurship as either an occupational or structural phenomenon. "Occupational theories 
define entrepreneurship as self-employment and treat the individual as the unit of analysis, describing the characteristics of individuals who start their own businesses and explaining the choice between employment and self-employment" (Klein 2008, 176). Classic exemplars of such an approach include Kihlstrom and Laffont's (1979) classic risk aversion model and Parker's (2009) composite review of the self-employment research.

Alternatively, "structural approaches treat the firm or industry as the unit of analysis, defining the entrepreneurial firm as a new or small firm. The literatures on industry dynamics, firm growth, clusters, and networks have a structural concept of entrepreneurship in mind" (Klein 2008, 176). This approach to the study of entrepreneurship was empirically popular among early entrepreneurship scholars (e.g. Acs and Audretsch 1989, 1990; Oakley, Rothwell, and Cooper 1988).

Notably, both of these approaches are clear in their implication for the autarkic economy-entrepreneurship is a catallactic phenomenon only. This is, perhaps, not surprising given that the positivistic foundations of mainstream economics imply that entrepreneurship exists in the market economy (and, so, is not to be found out of it).

\section{Austrian Economics}

The Austrian school of economics has set itself apart from the economic mainstream, among many other ways, by characterizing entrepreneurship as an economic function. Entrepreneurship is not something that exists in an economy, but is something that certain economic actors do, a function that they perform. Austrian theory has examined the role of the entrepreneur-what his purpose is and what effects he has on the economy-whereas mainstream economics, both neoclassical and Keynesian, has simply assumed away this role, taking the small business as already given (Casson 1982; Hébert and Link 1988, 2009). In other words, positive economics takes the entrepreneurial firm as extant and real, and so offers no theory of its emergence in the first place. In this only the Austrian school has had anything meaningful to say. Here let us consider the different entrepreneurship theories of the Austrians, 
namely those of Joseph A. Schumpeter, Mises, Israel M. Kirzner, and Ludwig M. Lachmann (ordered chronologically).

Although some do not include Schumpeter as a member of the Austrian school, in this sense he belongs with the Austrians. Schumpeter $(1934,66)$ conceived the function of the entrepreneur to be innovation, i.e., "the carrying out of new combinations," which he defined broadly to include the introduction of economic novelty to the market in five different categories:

(1) The introduction of a new good - that is one with which consumers are not yet familiar - or of a new quality of a good. (2) The introduction of [a] new method of production, that is one not yet tested by experience in the branch of manufacture concerned, which need by no means be founded upon a discovery scientifically new, and can also exist in a new way of handling a commodity commercially. (3) The opening of a new market, that is a market into which the particular branch of manufacture of the country in question has not previously entered, whether or not this market has existed before. (4) The conquest of a new source of supply of raw materials or half-manufactured goods, again irrespective of whether this source already exists or whether it has first to be created.

(5) The carrying out of new organization of any industry, like the creation of a monopoly position (for example through trustification) or the breaking up of a monopoly position.

Thus, Schumpeter's entrepreneur is the introducer of novelty into the production system, the disrupter of Walrasian equilibrium. Note that this entrepreneurial function is different from the "inventor" function, which merely devises the novelty. Although the inventor (who creates the novelty) and innovator (who brings it to market) are often the same person, they need not be. Although Schumpeter takes no interest in autarkic economics, one can infer from this that his entrepreneurship theory might include Noland or Crusoe whenever they innovated.

Mises's work on entrepreneurship is somewhat limited and yet remarkably profound. However, because it is limited, the essential function of the entrepreneur in Mises's treatment is somewhat unclear. The standard interpretation of the Misesean function of the entrepreneur is as speculator, the bearer of uncertainty and of risk ${ }^{3}$

\footnotetext{
${ }^{3}$ Whereas Knight (1921) describes risk as a situation of known outcome probabilities in contrast to uncertainty, Mises depicts risk as what one stands to lose within uncertain endeavors.
} 
in the allocative investment of scarce resources. While the capitalist earns interest and the worker earns wages, the entrepreneur is the one who "earns profit or suffers loss" (Mises 1951; 1998, 255). However, Mises $(1998,288)$ also, quite explicitly, observed that "The specific entrepreneurial function consists in determining the employment of the factors of production." Certainly, such resource allocation is speculation and necessarily bears uncertainty. But it is not clear whether the true essence of the entrepreneur is, for Mises, in the speculation or in the resource allocation. Rothbard and Kirzner assumed the former, Lachmann the latter. I will come back to this question shortly.

Mises (1998, 252-53) explicitly depicts the entrepreneurial function as a catallactic one. However, he seems to understand this characterization ("catallactic") more generally as an economic function, for also included among these "catallactic" functions are consumer, landowner, capitalist, and worker, all of which are autarkic economic functions also, and not merely confined to interpersonal market activities. ${ }^{4}$ Thus, although Mises formally discusses the entrepreneurial function as a "catallactic concept" only (Mises 1998, 253), it can certainly be extended to the autarkic economy also.

Although Kirzner's work has centered on the entrepreneurial function, the essence of this function has been rather difficult to pin down. Most understand Kirzner's entrepreneurial function to be the discovery of yet unexploited "opportunities," for which he has been much criticized (e.g., Foss and Klein 2010; Rothbard 1985, 1997). Thus, the unique feature that characterizes the entrepreneur is his "alertness" to such opportunities where others have overlooked them. But Kirzner's conception of an opportunity is rather unclear, especially as pertaining to autarkic versus catallactic processes. The standard definition of opportunity is as a "market imperfection" (Alvarez, Barney, and Anderson 2013), a situation in which the entrepreneur "buys where prices are 'too low' and sells where prices are 'too high'” (Kirzner 1997, 70), plausibly obtaining for himself a pure profit with no cost or risk to himself (Kirzner 1973). One footnote of particular relevance, however, illustrates the difficulty in interpreting Kirzner on this point:

\footnotetext{
${ }^{4}$ Although land ownership has little apparent meaning in a wholly isolated autarkic economy (à la Crusoe), in another sense property (e.g. land) ownership is what enables autarkic economy within the catallactic economy.
} 
In a world of perfect knowledge the only scope for decision-making relates to opportunities for exchange-either with man or with naturesomething one values relatively little for something one values more highly. In a world of imperfect knowledge, there may exist at any given time something selling at more than one price in the market. Once this price difference is noticed, once some knows it, a profit opportunity has been discovered. (Kirzner 1973, 37n4-38)

Observe here that Kirzner defines opportunity in two ways. In the first, it is a situation in which valued goods can be exchanged for something of higher value, thereby achieving a pure profit. In the second, he defines it as a situational price difference that can be exploited for a pure profit. Although these seem essentially equivalent, there is a critical difference, especially for the research at hand. Price differences, of course, necessarily imply a catallactic economy. However, according to his first definition of opportunity, such exchange-either with man or with nature-need not be catallactic, but apparently includes autarkic exchange "with nature" (such as exchanging valuable time and labor for the goods of nature acquired from those efforts). Thus, we can also ascribe to Kirzner an entrepreneurial function of new value discovery that fits both the autarkic and catallactic economy contexts.

Lachmann (1977, 1978), finally, sees entrepreneurs "as 'problem-solving' individuals who 'change' and 'direct capital flows'" (Endres and Harper 2013, 306). In other words, the essential function of Lachmann's entrepreneur is to reorganize capital more efficiently. In this sense, Lachmann's entrepreneur overlaps significantly with Schumpeter's and Mises's, and only lightly with Kirzner's. Lachmann expends some effort advancing the notion of capital, which is often, in traditional economics, understood to be given by its objective nature. Lachmann, however, rejects this objectivism-capital is only given by entrepreneurs, who create from the (objective) properties of things new and better (subjective) purposes or uses for those things, reconceptualizing them into new capital goods. For example, wood material is merely matter of a certain type until some entrepreneur imagines out of it the purpose of comfortably sitting and, thereby, creates out of that matter the capital good of "chair." Once again, while Lachmann theorized this entrepreneurial function within the context of the catallactic economy, it appears equally valid in an autarkic economy. 
Each of these entrepreneurship theories holds merit in depicting important economic functions that serve to explain economic change processes. However, each one seems to focus on a different economic mechanism, which prompts us to ask, again, what is the real entrepreneurial function?

\section{The Entrepreneurial Function Reconceptualized}

There is, perhaps, no "right" answer to the question of what the entrepreneurial function is. The question is definitional and, thus, analytic and tautological. Each of the functions outlined above is a real economic function, with specific and relevant economic effects. By what criteria might we determine which is the most apropos to economic theory?

It seems that the best and, in fact, only criterion that could direct such a judgment is the economic effect that one seeks to explain by the concept of entrepreneurship. To make this argument, let us follow the standard Austrian method of starting with the artificial foil to which we will add the entrepreneur-a society in which there are no entrepreneurs whatsoever. Let us start with Mises's evenly rotating economy (ERE).

\section{The Evenly Rotating Economy}

The ERE is "a fictitious system in which the market prices of all goods and services coincide with the final prices. There are, in its frame, no price changes whatever; there is perfect price stability. The same market transactions are repeated again and again" (Mises 1998, 248).

What would occur if value scales, technological ideas, and the given resources remained constant? What would then happen to prices and production and their relations? Given values, technology, and resources, whatever their concrete form, remain constant. In that case, the economy tends toward a state of affairs in which it is evenly rotating, i.e., in which the same activities tend to be repeated in the same pattern over and over again. Rates of production of each good remain constant, all prices remain constant, total population remains constant, etc. (Rothbard 2009, 321) 
The ERE allows us to "analyze the problems of change in the data and of unevenly and irregularly varying movement" (Mises 1998, 248). There is no uncertainty in the ERE whatever; all actions are perfectly predictable, and all actors are mere automatons, performing perfectly their prescribed duties. Thus, the ERE is a "state of final equilibrium" (Rothbard 2009, 321).

\section{Adding the Entrepreneurial Function}

Let us now add the entrepreneurial function to the ERE, where we have no economic change whatsoever. To understand what sort of change is introduced by the entrepreneur to the ERE, we have to first examine what the entrepreneur is trying to accomplish-i.e., what is the goal of the entrepreneur? The purpose that drives the entrepreneur is distinct from that of the "manager," whose role is circumscribed to "a limited and precisely determined sphere of action" (Mises 1998, 301), namely the (re)production of goods according to established plans. The aim of the entrepreneur, and of the entrepreneurial function, is to generate and purvey such "entrepreneurial plans" (Lachmann, 1977, 1986; Mises, 1998, 300). These plans-distinct from the managerial function of carrying out existing plans for economic value facilitation through productionare pursuant of new and better ways to economize existing resources and activities. They seek to facilitate a higher economic state, to achieve economic growth. Such economic change is accomplished in several ways. We focus here on the effected changes, driven by the entrepreneurial function, on "values, technology, and resources" (Rothbard 2009, 321), which can no longer be held constant.

First and perhaps foremost, economic change can be accomplished by changing the technology by which resources are employed toward need satisfaction. By creating new knowledge about what resources can do, by reconfiguring resources into "New Combinations" (Schumpeter 1934) or new forms of capital (Lachmann 1978), new solutions are created whereby total need satisfaction might be augmented, thereby achieving a higher economic state. Or else the new solution might prove ineffective, and the resources taken away from their more productive uses are wasted in ineffective production, generating an economic loss. 
Second, this economic change can be accomplished by reallocating resources more effectively. Under the ERE, present resource allocations are merely replicated, oblivious to any possible gains that might be achieved through optimization. The entrepreneurial function, however, may alter presently inefficient resource allocations toward more highly valued ends (Kirzner 1973), facilitating economic growth. Again, there is a chance that such reallocation results in economic loss, the previous resource allocation proving the more valuable or else the cost of reallocation proving too steep to warrant the change.

Third and, perhaps, least discussed, economic change can be accomplished by the shifting of subjective values. If, as some philosophies and religions teach, humankind were to learn greater contentment within their present world of scarcity, total economic value and satisfaction might increase with no changes to the productive structure whatsoever. That is, because satisfaction is a subjective state—a state of mind — such a state can be achieved by altering the mind rather than the exogenous effects on it. However, it is also possible that people instead learn to want more and more, to become increasingly or perpetually dissatisfied, as has become common in the modern age of consumerism and instant gratification. Thus, shifting subjective values can also either increase or decrease total aggregate well-being. Strictly, the entrepreneur has no direct access to such subjective values, which are the sole purview of individual consumers, to effect such change. However, it is within the entrepreneur's purview to influence such change by "pushing and promoting" (Mises 1998, 255) their ideas.

In short, by introducing changes to an economy by shifting resource allocations, the entrepreneurial function introduces a profit and loss mechanism (Mises 1951, 1998). But let us be careful here. Although entrepreneurship is a primary source of economic profit and loss, it is not the only one in a real economy. Were we to relax the ERE to allow changes not instigated by entrepreneurs, it is possible that such changes, such as shifting demand, depleting supply, etc., would also cause economic shifts, up or down. If, instead of adding the entrepreneurial function to the ERE, we added only the ability for demand to change, such shifts in demand would also cause economic growth or decline. If, all else held constant, consumers suddenly changed their 
preferences from blue shirts toward orange shirts, the supply of blue shirts would suddenly become excessive and the supply of orange shirts would then be insufficient, producing an economic decline. Or, if supply were allowed to change, newly discovered supplies might increase total satisfaction outputs, while depleted supplies would cause markets that require the supply to evaporate, leaving consumers less satisfied.

Thus, the entrepreneurial function generates economic profits or losses, causing growth or decline. It is not the only source of such change, but it is the most consequential. And, perhaps more importantly, although other allowed economic changes might result in greater or lower economic value, entrepreneurship is intentional, pursuant always of greater individual well-being and, thus, economic value. While entrepreneurial failure is common, entrepreneurs generally accept the risks of such venturing only when economically feasible, the risks worth the rewards. Thus, the tendency of entrepreneurship-driven change is toward economic growth, which is why societies that promote greater entrepreneurial activity tend to see higher rates of economic growth (Bjørnskov and Foss 2013, 2016; Holcombe 1998; Packard and Bylund 2018). However, as Baumol (1990) reminds us, some entrepreneurs' individual pursuit of economic value may come at the expense of others' well-being and so may not be net productive. Furthermore, intending to generate new economic value does not imply success, and the efforts of doing so can result in resource maldistribution and loss. Thus, while entrepreneurship is the engine for economic growth, not all entrepreneurship will result in such growth.

But what is the ultimate source of this economic growth? Is it innovation (Schumpeter 1934)? Opportunity discovery and exploitation (Kirzner 1973; Shane 2003)? Perhaps opportunity creation (Alvarez and Barney 2007)? Or capital allocation/investment in uncertainty (Foss and Klein 2012; Lachmann 1978)? The answer to all of these seems to be yes. Each of these economic subprocesses contains the profit/loss function that characterizes entrepreneurship. Each of them bears uncertainty, generating profit when successful and 
losses when not. ${ }^{5}$ The entrepreneurial function that we are seeking is, thus, broader than any of these specifically.

Let us step back from such specifics and proffer a more general and generalizable definition of entrepreneurship, then. The essential features of the entrepreneurial function, based on this analysis, include intentionality toward economic (psychic) profit and the commitment of resources (broadly defined) to do so. Thus, we can define entrepreneurship as "the intentional pursuit of new economic value" (Packard 2017, 544) through resource investment. By "economic value" we again mean a general increase in individual, subjective well-being. Generally, then, such endeavors are the source of new economic growth, which is again understood as an overall increase in the quality of life. This definition captures the entrepreneurial function as a whole and all types of entrepreneurial activities, while excluding unintentional sources of economic change.

If entrepreneurship entails all intentional pursuits of new economic value, such pursuits would entail pursuits of increases to and betterments of need satisfactions. They would include product and process innovations and improvements. They would include large and small changes. And they would include each and every previously defined entrepreneurial function reviewed above.

\section{A REASSESSMENT OF THE MISESEAN ENTREPRENEUR}

Let us return here to the ambiguities in Mises's defining of the entrepreneurial function. It is proposed that a more careful reading of Mises lands us on an understanding of the entrepreneurial function that is essentially equivalent to the one that we have just arrived at. However, it is rather different from the one widely supposed within modern Austrian academia.

\footnotetext{
${ }^{5}$ Kirzner (1973), of course, supposes that the pure entrepreneurial function can be employed without any capital investment and, thus, risk of loss whatsoever. But Kirzner errs here in failing to account for the autistic exchange (Mises 1998, 195-96) of the entrepreneurial endeavor. A "pure" entrepreneur still must expend time and effort, which might have been employed in other productive efforts, which can be lost in the case of failure. There can, in fact, be no entrepreneurship without uncertainty or risk of loss.
} 
The modern view of Mises's entrepreneurial function is as speculator, the bearing of uncertainty. "Like every acting man, the entrepreneur is always a speculator" (Mises 1998, 288). Accordingly, it is supposed that entrepreneurship is inherent in all human action to some extent. Rothbard $(2009,64)$ explains:

This process of forecasting the future conditions that will occur during the course of his action is one that must be engaged in by every actor. This necessity of guessing the course of the relevant conditions and their possible change during the forthcoming action is called the act of entrepreneurship. Thus, to some extent at least, every man is an entrepreneur. Every actor makes his estimate of the uncertainty situation with regard to his forthcoming action.

I find this conclusion to be untenable for a few reasons. The first, and a common challenge made by those outside of the Austrian school, is that if all action is entrepreneurship, then none is. In other words, if we cannot separate "entrepreneurship" from "action" broadly, then the concept of entrepreneurship is redundant and useless. It provides no additional insight beyond our general understanding of human action, which also is always uncertain. Second, the prevailing interpretation implies that because all action is entrepreneurial, none is managerial. Clearly, Mises did not intend such a conclusion, as will be shown. Finally, the foregoing analysis of the entrepreneurial function-concluding that its essence is in the intentional pursuit of new economic value-implies that uncertainty bearing is a necessary consequence of entrepreneurship and not its essence. Read in that way, Mises's theory comes into better focus, as will also be shown.

\section{Is All Action Entrepreneurial?}

Scholars who have adopted a definition of the entrepreneurial function as speculator have, it seems, misread Mises. Here we find the primary source of the confusion:

Like every acting man, the entrepreneur is always a speculator. He deals with the uncertain conditions of the future. His success or failure depends on the correctness of his anticipation of uncertain events. If he fails in his understanding of things to come, he is doomed. The only source from which an entrepreneur's profits stem is his ability to anticipate better than 
other people the future demand of the consumers. If everybody is correct in anticipating the future state of the market of a certain commodity its price and the prices of the complementary factors of production concerned would already today be adjusted to this future state. Neither profit nor loss can emerge for those embarking upon this line of business.

The specific entrepreneurial function consists in determining the employment of the factors of production. The entrepreneur is the man who dedicates them to special purposes. In doing so he is driven solely by the selfish interest in making profits and in acquiring wealth. But he cannot evade the law of the market. He can succeed only by best serving the consumers. His profit depends on the approval of his conduct by the consumers. (Mises 1998, 288)

Mises points out here that all entrepreneurship, like all action, is speculative. But to read this, as Rothbard does, to imply that speculation or forecasting is entrepreneurship is not here justified. Instead, all entrepreneurship is a type of human action and, like all human action, is speculative. In fact, it is one of the most speculative types of human action.

However, while all entrepreneurship is action, the reverse is not true-not all action is entrepreneurship. In Rothbard's interpretation, he does not go so far as to claim all action to be entrepreneurship, as such an interpretation intuitively seems false. Instead, he claims all action to be entrepreneurial to some extent, the extent being that to which the action bears uncertainty. Yet, of course, this leads to a recognition that all action is entrepreneurship, although some actions are more "entrepreneurial" than others.

One problem with this is that a lot of uncertainty bearing is not entrepreneurial whatsoever, at least not intuitively. Is a student an entrepreneur when guessing on an ungraded pop quiz? Is an art observer an entrepreneur when wondering who painted the lovely seascape? Is a historian an entrepreneur when uncertain as to the true underlying causes of World War I? These types of uncertainty bearing have no obvious economic effects, as they have no effects on the structure of production. At best, one could argue that such uncertainty bearing affects consumption outcomes, but such an argument is tenuous. One can be uncertain about a great many things that do not matter at all to that person.

Perhaps we could augment the speculative entrepreneurial function to include risk bearing, requiring some investment, which seems more 
plausible. But the essence of this risk is in the investment and not only in the uncertainty. Action without investment is not entrepreneurial.

\section{The Managerial Function}

It is clear in Mises's writing that the "managerial function" (Mises $1998,302)$ is a real function within the catallactic economy. Mises $(1998,301)$ describes the manager as "a junior partner of the entrepreneur" who attends "to the entrepreneurial functions which are assigned to him within a limited and precisely determined sphere of action." In short, the entrepreneur delegates the responsibilities of carrying out his plans to the manager. It is not the function of the manager to devise the plans, which are provided by the entrepreneur. Instead, the managerial function "is to adjust-within the limited scope left to his discretion-the operation of his section to the state of the market" (Mises 1998, 302). The manager is, thus, given discretion to operate within a "limited scope" or "section" of market processes. Mises then quickly acknowledges that, often, the entrepreneurial, managerial, technician, and other market functions are performed by the same person.

Again, defining all action as entrepreneurial leaves no room for this managerial function, which must thus be circumscribed to some artificial world, such as the ERE, where action may be certain. Clearly, this was not Mises's intention (see Mises 1998, 300-07), which again forces us to reconsider how he understood entrepreneurship.

\section{The Essence of Entrepreneurship}

It is my argument, then, that Lachmann, and not Rothbard, reads Mises most correctly here. The essence of entrepreneurship is, for Mises $(1998,288)$, in "determining the employment of the factors of production." Assuming that, in particular, Mises is referring to the entrepreneur's changing the allocation of these factors of production, which seems apparent from his elaboration that entrepreneurs dedicate these resources to "special purposes," speculation and the bearing of uncertainty naturally follow from this function. Thus, "[1]ike every acting man, the entrepreneur is always a speculator" (ibid., 288). But these consequences are not 
the essential function itself, and not all speculators are necessarily entrepreneurs. Any speculation without resource (re)commitment is simply idle wondering, and not entrepreneurship. In contrast, "the function of the entrepreneur cannot be separated from the direction of the employment of factors of production for the accomplishment of definite tasks" (ibid., 302). Thus Mises, like Lachmann, sees the entrepreneurial function as the formulation of "entrepreneurial plans" (ibid., 300), the productive task to which invested resources are to be put, which plans are then carried out by managers (and "submanagers"), who implement the plans via the employment of technicians.

If we accept this reconception of Mises's entrepreneurial function, then to what end are such essential plans directed? Mises makes it clear that entrepreneurs are "driven solely by the selfish interest in making profits and in acquiring wealth" (ibid., 288), which profits he again defines as an "increase in satisfaction (decrease in uneasiness) brought about" (ibid., 286). Entrepreneurship is always intentional, directed toward an increase in subjective value, i.e., subjective well-being. Thus, the entrepreneurial function-the formation of new entrepreneurial plans-can be restated in the very same language we arrived at previously: entrepreneurship is the intentional pursuit of new economic value through resource investment.

\section{THE AUTARKIC ENTREPRENEUR}

Adopting this general definition of entrepreneurship here, let us circle back to the notion of an autarkic entrepreneur. Can Noland or Crusoe or a do-it-yourselfer intentionally pursue new economic value through resource investment? Clearly, the answer is yes. Thus, entrepreneurship is not a catallactic function only, but is a key function and aspect of all human existence, conjointly or alone. Autarkic economizers can perform the entrepreneurial function also.

But what does this autarkic entrepreneur look like? Let us take the standard fictitious Robinson Crusoe example as our starting point here before moving on to more practical and real applications of autarkic entrepreneurship. 


\section{Isolated Autarky}

Let us begin our analysis with the case of isolated autarky or the "isolated household economy," where there is but a single economic producer (whether it is a lone and isolated actor or, else, all other actors in the "household" are wholly unproductive and dependent). In this case, the entire economy is "at the disposal of a single economizing individual" (Menger 2007, 75). Consider Robinson Crusoe (pre-Friday) in the state of nature. What are the intentions that motivate his actions? Following the standard Misesean framework, Crusoe's aim is universally directed at a higher state of well-being. This includes, firstly, survival—the bare necessities. Thereafter, increasing productivity and savings would allow him to incrementally allocate more of his time and action to the pursuit of more and better satisfactions of his various needs.

Thus, immediately, the autarkic entrepreneurial function rears its head. To begin, Crusoe must go from no production (other than, perhaps, getting his bearings) upon finding himself on the island-a state of affairs that would not do as a stationary economy-and increase production to a level above the survivability threshold. He must generate sufficient new economic value in order to meet the consumption demands of a properly functioning body-he must grow the economy to a level of basic sustainability. Given our definitions of economy and the entrepreneurial function within it, this means that survival, for Crusoe, requires entrepreneurship.

The autarkic entrepreneurial function, which Crusoe adopts, generates entrepreneurial plans to discover and allocate resources in a more productive way. One such plans are generated, the entrepreneurial Crusoe gives way to the managerial Crusoe, who then implements the plans purveyed by entrepreneurial Crusoe. At times, the entrepreneurial plan may go awry, and entrepreneurial Crusoe reemerges to reassess and revise the plan (see Packard, Clark, and Klein 2017). Additional revisions and new entrepreneurial plans may also arise as new information becomes available. In short, autarkic Crusoe bounces between distinct producer functions so that, in the end, consumer Crusoe can enjoy the spoils of those productive efforts.

It is the autarkic entrepreneurial function, however, that devises autarkic plans of action. Once those plans are devised, the role of 
the autarkic entrepreneur is completed and passes to the managerial function. In fact, once Crusoe's economy has reached a level of sustainability, the entrepreneurial function is no longer strictly required, and Crusoe could plausibly maintain the same production plan for survival, merely replicating time and again the established level of subjective well-being until there is some change in supply or demand. However, it is unlikely that Crusoe would voluntarily stand pat at a minimum level of sustenance. As productivity increases (through, e.g., learning curves), Crusoe may find enough time and savings to invest in capital goods. This investment is another case of autarkic entrepreneurship to further increase future well-being by employing saved resources in developing useful tools that might increase overall productivity. Or, perhaps, the attained level of productivity may be such that he can turn to other productive activities aimed at better satisfying other, nonessential needs (e.g., building more comfortable furnishings) or otherwise improving the satisfaction of the essential needs (e.g., pursuing a wider variety of foods). All such activities are entrepreneurial, aimed at creating new economic plans for value attainment. While Crusoe may very well go through periods of managerial persistence, we would expect him to be always on the lookout-Kirzner's 'alertness' - for new ways to better address those still imperfectly satisfied needs.

Through repeated entrepreneurial endeavors, Crusoe's one-man economy can plausibly attain a level of productivity that may be quite comfortable to him. In other words, Crusoe could, through entrepreneurial efforts, plausibly grow his economy of one to a quite high level of subjective well-being. However, he alone could never approach the levels of productivity, economic growth, and total satisfaction that could be achieved through catallactic economizing.

\section{Normal Autarky}

Although the isolated autarky illustration is apt and useful in illustrating the entrepreneurial function within the autarkic economy, it holds little obvious practical relevance to the typical economic actor. However, autarkic economics, including the entrepreneurial function within it, is in fact very relevant and important to economic theory and to the real world, as has already been argued. Thus, let 
us now expand our autarkic economy to the typical and everyday situation-the normal autarkic economy.

This normal autarkic economy is embedded within and interacts with the catallactic economy. However, "normal autarky" refers to those productive economic activities that are performed outside of the catallactic economy-those which individual actors (or households) perform for themselves. This normal autarkic economy includes, as previously indicated, home cooking, homemaking, pursuing hobbies, maintaining personal hygiene, rest and sleep, and other activities that are either not available in the catallactic economy or where the marginal benefits of the market options do not supersede the costs of DIY.

To motivate this theory, consider the following research by von Hippel, de Jong, and Flowers $(2012,1669)$ :

Our study finds consumer innovation to be quite significant in both scale and scope. Via a survey of a representative sample of 1,173 consumers in the United Kingdom, we estimate that $6.1 \%$ of UK residents 18 years of age or older have created or modified consumer products they use during the prior three years. This represents nearly 29 million people. In aggregate, we find that UK consumer product users spend 97,800 person-years and an estimated $£ 3.2$ billion annually on their development efforts - more than 1.4 times the consumer product $R \& D$ expenditures of all firms in the United Kingdom combined. We also find that consumer product innovation spans a wide range of fields, from toys, to tools, to sporting equipment, to personal solutions for medical problems. We further discover that consumer-developed innovations appear to be complements rather than substitutes for producer innovations, and that consumer innovators very seldom protect their innovations via intellectual property; in fact, $17 \%$ diffuse to others.

This suggests that there is a vast array of autarkic economies booming under our noses, with frequent entrepreneurial endeavors by which new solutions are innovated and existing (catallactic) solutions are altered and augmented.

Most of these innovations are never taken to market, remaining the purview of autarkic economy and not of catallactic economy, even though many of them appear to solve a real market need. Some have ascribed this tendency for good entrepreneurial solutions to remain confined to the autarkic economy to a market failure (de Jong et al. 
2015; de Jong, Gillert, and Stock 2018). However, in fact, catallactic entrepreneurship is quite different from autarkic entrepreneurshipit requires very different skillsets, vastly more time and effort, and the bearing of significantly more uncertainty and risk. That is, there are-or may be-very good reasons to confine entrepreneurial efforts only to autarky, even in the presence of a large and booming catallactic economy and significant market potential.

Thus, autarkic entrepreneurship is very different in scope and function from catallactic entrepreneurship. The former may lead, in some cases, to the latter, as in the case of so-called user entrepreneurship (Shah and Tripsas 2007). However, this is, as we have seen, not always the case, as vast amounts of autarkic entrepreneurship stay confined to their respective autarkic economies. Furthermore, there appear to be many cases of catallactic entrepreneurship that do not clearly start within an autarkic economy. In such cases, the entrepreneurial plans characteristic of the entrepreneurial function are, in the first place, devised for the satisfaction of others' needs, whereby the catallactic entrepreneur might gain profit for themself through catallactic exchange.

\section{The Boundary between Autarkic and Catallactic Entrepreneurship}

The scope of this paper is not a full elaboration of a theory of autarkic entrepreneurship, which would require a much larger treatment. My aim has been only to make a compelling case that there is a real autarkic economy and that the entrepreneurial function operates within it. Furthermore, it is to assert that the autarkic entrepreneur is different from and performs a different function than the catallactic entrepreneur. This is, thus, a call for new theorizing on a prominent type and area of economic activity that has been neglected.

However, to perhaps get this ball rolling, let me lay down some initial legwork with regard to the normal operations of the autarkic economy in relation to the catallactic economy, specifically in regard to the entrepreneurial function of each. In other words, why are some entrepreneurial activities pursued in the autarkic economy and others in the catallactic economy? What are the boundary conditions that separate them? One answer is likely to be the 
amount of needed capital, including human capital, required for the innovation and production of certain solutions. Thus, Schultz's (1975, 1979, 1980a, 1980b) human capital approach to entrepreneurship may be a good starting place for such explorations.

Another key factor must, of course, be the transaction costs of catallactic versus autarkic exchange. Transaction cost economics, which compares a firm's internal versus external transaction costs to determine its proper scope (Grossman and Hart 1986; Holmstrom and Roberts 1998), might be adapted to compare autarkic and catallactic transaction costs and, thereby, help determine the "scope" of the autarkic economy vis-à-vis the catallactic economy. For example, while catallactic transaction costs involve costs of triangulation, transfer, and trust (Munger 2018), autarkic exchange largely skirts the bulk of these costs, its transaction costs involving primarily uncertainties. Similarly, the cost-benefit calculations themselves may also vary between catallactic and autarkic economies (see Piano and Rouanet 2020).

A third factor is the fact that catallactic markets can benefit from a division of labor, whereas autarkic exchange cannot.

These factors tie into another important area of future research, which would explore how these distinct economies, and their entrepreneurial functions, interact. For example, when are autarkic innovations taken to market or not (de Jong, Gillert, and Stock 2018; de Jong et al. 2015; von Hippel, de Jong, and Flowers 2012)? And how and when are catallactic solutions "internalized" by the autarkic economy-i.e., when do market solutions become DIY solutions?

Relatedly, how and when do these distinct economies support each other? For example, DIY services (e.g., home improvement retailers, medical self-diagnosis websites such as WebMD.com, and legal document creation aids such as LegalZoom.com) are quite large and profitable catallactic industries that serve as suppliers and support services for the autarkic economy. This is exemplified by The Home Depot's marketing slogan: "You can do it. We can help." Or, on the other hand, some retailers leverage consumer human capital (or just "consumer capital"), facilitating greater value for their customers by leveraging autarkic production in so-called (somewhat imprecisely) value co-creation (Ramírez 1999; Ratchford 2001; Vargo and Lusch 2004; Vargo, Maglio, and Akaka 
2008). For example, IKEA gained an advantage over its competitors by offering high-quality furniture at a steeply discounted price by leveraging its customers' willingness to assemble the furniture themselves. In other words, IKEA outsourced the last steps of the value chain to the autarkic economy.

In short, there are clear and obvious benefits to autarkic economic activities-including entrepreneurship - that may not obviously translate to the catallactic economy. One reason is the personal nature of the need and its solution, which, perhaps, makes the solution economically infeasible for catallactic production, having too narrow a market. Said differently, some activities may be pursued through autarkic entrepreneurship out of necessity due to a persistent absence of those activities in the catallactic economy. Other reasons include costs, convenience, and the mere enjoyment of producing (e.g., hobby gardening, crafting, or woodworking). These reasons and boundaries are the subject of much needed future research.

\section{CONCLUSION}

The aim of this article has been to expand and legitimize the Austrian theory of autarkic (autistic) economy and, especially, the entrepreneurial function within it. Entrepreneurship is not merely a catallactic function but plays a far more prevalent role in economic life than has hitherto been proffered. In fact, we act as entrepreneurs quite regularly — even daily—as we look at our routines and decide to try new things instead: new recipes, new activities, new friendships, new furniture arrangements, etc. In other words, we act as entrepreneurs whenever we take our existing stock of capital and enact plans to shift them into new arrangements and combinations to produce, hopefully, better value outcomes (cf. Schultz 1975, 1980a).

Because life is an endless pursuit of ever higher value states (Packard 2019), because we continuously seek ever better satisfactions of our needs (Witt 2001), entrepreneurship plays a key and frequent role in our trying to grow our autarkic economy, to increase total well-being out of the resources possessed. This role is different from the oft-supposed function of uncertainty bearing that characterizes all human action. It is true that much of our day is employed in the management function, carrying out previously 
laid entrepreneurial plans and rotely replicating value states previously established by our entrepreneurial activities. We wake up at our routine time, ready ourselves routinely for the day, eat at routine times, and go through the day doing many of the same things by rote. But it is the entrepreneurial function-the autarkic entrepreneur-that breaks this routine, that tries something new.

The autarkic entrepreneur performs this function for the same reasons as the catallactic entrepreneur-in pursuit of new and superior economic value. Certainly, the catallactic entrepreneur is far more consequential, altering the value state of vast swaths of benefited economic actors through large-scale production and market interaction. For this reason, the catallactic entrepreneur has been rightly placed at the forefront of economic theorizing (at least in the Austrian tradition). However, this attention has caused the theoretical neglect of the autarkic entrepreneur, who is in fact a key economic actor also.

If I may be so bold, the neglect of the autarkic entrepreneur has been one of the most significant oversights of all of economics, including the Austrian school (which has, at least, somewhat recognized it). By bringing the autarkic, DIY economy into the theoretical frame, we observe a great number of insights into the boundaries of catallaxy and autarky. Without these, economics, including catallactics, is simply incomplete.

\section{REFERENCES}

Acs, Zoltan J., and David B. Audretsch. 1989. "Small-Firm Entry in US Manufacturing." Economica 56: 255-65.

—_. 1990. Innovation and Small Firms. Cambridge, Mass.: MIT Press.

Alvarez, Sharon A., and Jay B. Barney. 2007. "Discovery and Creation: Alternative Theories of Entrepreneurial Action." Strategic Entrepreneurship Journal 1, no. 1-2: 11-26.

Alvarez, Sharon A., Jay B. Barney, and Philip Anderson. 2013. "Forming and Exploiting Opportunities: The Implications of Discovery and Creation Processes for Entrepreneurial and Organizational Research." Organization Science 24 no. 1:301-17. 
Baumol, William J. 1990. “Entrepreneurship: Productive, Unproductive, and Destructive." Journal of Political Economy 98, no. 5, part 1: 893-921.

Becker, Gary S. 1965. "A Theory of the Allocation of Time." Economic Journal 75, no. 299: 493-517.

— . 1991. A Treatise on the Family, enlarged ed. Cambridge, Mass.: Harvard University Press.

Bjørnskov, Christian, and Nicolai Foss. 2013. "How Strategic Entrepreneurship and the Institutional Context Drive Economic Growth." Strategic Entrepreneurship Journal 7, no. 1: 50-69.

_ 2016. "Institutions, Entrepreneurship, and Economic Growth: What Do We Know and What Do We Still Need to Know?" Academy of Management Perspectives 30, no. 3: 292-315.

Bylund, Per. L. 2016. The Problem of Production: A New Theory of the Firm. Abingdon, U.K.: Routledge.

Casson, Mark. 1982. The Entrepreneur: An Economic Theory. Totowa, N.J.: Barnes and Noble Books.

de Jong, Jeroen P. J., Nils Lennart Gillert, and Ruth M. Stock. 2018. “First Adoption of Consumer Innovations: Exploring Market Failure and Alleviating Factors." Research Policy 47, no. 2: 487-497.

de Jong, Jeroen P. J., Eric von Hippel, Fred Gault, Jari Kuusisto, and Christina Raasch. 2015. "Market Failure in the Diffusion of Consumer-Developed Innovations: Patterns in Finland. Research Policy 44, no. 10: 1856-65.

Deci, Edward L. 1980. The psychology of self-determination. Lexington, Mass.: Lexington Books.

Deci, Edward L., and Richard M. Ryan. 2000. "The 'What' and 'Why' of Goal Pursuits: Human Needs and the Self-Determination of Behavior." Psychological Inquiry 11, no. 4: 227-68.

Devine, James G. 2003. "Psychological Autism, Institutional Autism and Economics." Pp. 212-220 in The Crisis in Economics. The post-autistic economics movement: the first 600 day, ed. Edward Fullbrook. New York: Routledge.

Endres, Anthony M., and David A. Harper. 2013. "'Wresting Meaning from the Market': A Reassessment of Ludwig Lachmann's Entrepreneur." Journal of Institutional Economics 9, no. 3: 303-28. 
Foss, Nicolai J., and Peter G. Klein. 2010. “Entrepreneurial Alertness and Opportunity Discovery: Origins, Attributes, Critique." Pp. 98-120 in Historical Foundations of Entrepreneurship Research, ed. Hans Landström, and Franz Lohrke. Northampton, Mass.: Edward Elgar.

Foss, Nicolai J., and Peter G. Klein. 2012. Organizing Entrepreneurial Judgment: A New Approach to the Firm. Cambridge: Cambridge University Press.

Gartner, William. B. 1988. “'Who Is an Entrepreneur?' Is the Wrong Question." American Journal of Small Business 12, no. 4: 11-32.

Grossman, Sanford J., and Oliver D. Hart. 1986. "The Costs and Benefits of Ownership: A Theory of Vertical and Lateral Integration." Journal of Political Economy 94, no. 4: 691-719.

Hébert, Robert F., and Albert N. Link. 1988. The Entrepreneur: Mainstream Views and Radical Critiques. $2 \mathrm{~d}$ ed. New York: Praeger.

— 2009. A History of Entrepreneurship. London: Routledge.

Hippel, Eric von, Jeroen P. J. de Jong, and Stephen Flowers. 2012. "Comparing Business and Household Sector Innovation in Consumer Products: Findings from a Representative Study in the United Kingdom." Management Science 58, no. 9: 1669-81.

Holcombe, Randall G. 1998. "Entrepreneurship and Economic Growth." Quarterly Journal of Austrian Economics 1, no. 2: 45-62.

Holmstrom, Bengt, and John Roberts. 1998. "The Boundaries of the Firm Revisited." Journal of Economic Perspectives 12, no. 4: 73-94.

Kihlstrom, Richard E., and Jean-Jacques Laffont. 1979. "A General Equilibrium Entrepreneurial Theory of Firm Formation Based on Risk Aversion." Journal of Political Economy 87, no. 4: 719-48.

Israel M. Kirzner. 1973. Competition and Entrepreneurship. Chicago, Ill.: University of Chicago Press.

— 1997. "Entrepreneurial Discovery and the Competitive Market Process: An Austrian Approach." Journal of Economic Literature 35, no. 1: $60-85$.

Klein, Peter G. 2008. Opportunity Discovery, Entrepreneurial Action, and Economic Organization. Strategic Entrepreneurship Journal 2, no. 3: 175-90. 
Knight, Frank. H. 1921. Risk, Uncertainty and Profit. New York: Houghton Mifflin Company.

Lachmann, Ludwig M. 1977. Capital, Expectations, and the Market Process: Essays on the Theory of the Market Economy. Ed. Walter E. Grinder. Kansas City, Kans.: Sheed Andrews and McMeel, Inc.

— 1978. Capital and Its Structure. Kansas City, Kans.: Sheed Andrews and McMeel.

_ 1986. The Market as an Economic Process. New York: Blackwell.

Lancaster, Kelvin. 1975. "The Theory of Household Behavior: Some Foundations." Annals of Economic and Social Measurement 4, no. 1: 5-21.

Menger, Carl. 2007. Principles of Economics. Trans. James Dingwall and Bert F. Hoselitz. Auburn, Ala.: Ludwig von Mises Institute.

Michael, Robert T., and Gary S. Becker. 1973. "On the New Theory of Consumer Behavior." Swedish Journal of Economics 75, no. 4: 378-96.

Mises, Ludwig von. [1912] 2009. The Theory of Money and Credit. Trans. J. E. Batson. Auburn, Ala: Ludwig von Mises Institute.

- 1951. Profit and Loss. South Holland, Ill.: Consumers-Producers Economic Services.

- 1998. Human Action: A Treatise on Economics. Scholar's ed. Auburn, Ala.: Ludwig von Mises Institute.

Munger, Michael C. 2018. Tomorrow 3.0: Transaction Costs and the Sharing Economy. Cambridge: Cambridge University Press.

O'Hara, Denis J. 2011. "Psychotherapy and the Dialectics of Hope and Despair." Counselling Psychology Quarterly 24, no. 4: 323-29.

Oakley, Ray, Roy Rothwell, and Sarah Cooper. 1988. The Management of Innovation in High Technology Small Firms: Innovation and Regional Development in Britain and the United States. Westport, Conn.: Quorum Books.

Packard, Mark D. 2017. "Where Did Interpretivism Go in the Theory of Entrepreneurship?" Journal of Business Venturing 32, no. 5: 536-49.

_ . 2019. "Entrepreneurship: Toward the Nirvana State of Rest." MISES 7, no. 3: 523-43. 
Packard, Mark D., and Per L. Bylund. 2018. “On the Relationship between Inequality and Entrepreneurship." Strategic Entrepreneurship Journal 12, no. 1: 3-22.

Packard, Mark D., Brent B. Clark,and Peter G. Klein. 2017. “Uncertainty Types and Transitions in the Entrepreneurial Process." Organization Science 28, no. 5: 840-56.

Parker, Simon C. 2009. The Economics of Entrepreneurship: Cambridge: Cambridge University Press.

Piano, Ennio E., and Louis Rouanet. 2020. “Economic Calculation and the Organization of Markets." Review of Austrian Economics 33: 333-48.

Pollak, Robert. A. 1985. "A Transaction Cost Approach to Families and Households." Journal of Economic Literature 23, no. 2: 581-608.

Ramírez, Rafael. 1999. "Value Co-production: Intellectual Origins and Implications for Practice and Research." Strategic Management Journal 20, no. 1: 49-65.

Ramoglou, Stratos, William B. Gartner, and Eric W. K. Tsang. 2020. “'Who Is an Entrepreneur?" Is (Still) the Wrong Question." Journal of Business Venturing Insights 13: e00168.

Ratchford, Brian T. 2001. "The Economics of Consumer Knowledge." Journal of Consumer Research 27, no. 4: 397-411.

Read, Leonard E. 1958. “I, Pencil.” Freeman, December 1958.

Rothbard, Murray N. 1985. "Professor Hébert on Entrepreneurship." Journal of Libertarian Studies 7, no. 2: 281-86.

_ 1997. "The Present State of Austrian Economics." Pp. 111-172 in The Logic of Action One: Method, Money, and the Austrian School. Cheltenham, U.K.: Edward Elgar.

- 2009. Man, Economy, and State with Power and Market. $2 \mathrm{~d}$ scholar's ed. Auburn, Ala.: Ludwig von Mises Institute.

Schultz, Theodore W. 1975. "The Value of the Ability to Deal with Disequilibria." Journal of Economic Literature 13, no. 3: 827-46.

—_ 1979. "Concepts of entrepreneurship and agricultural research." Kaldor Memorial Lecture, Iowa State University, Ames, Iowa. 
. 1980a. "Investment in Entrepreneurial Ability." Scandinavian Journal of Economics 82, no. 4: 437-48.

. 1980b. "Nobel Lecture: The Economics of Being Poor." Journal of Political Economy 88, no. 4: 639-51.

Schumpeter, Joseph A. 1934. The Theory of Economic Development: An Inquiry into Profits, Capital, Credit, Interest, and the Business Cycle. Trans. Redvers Opie. Cambridge, Mass.: Harvard University Press.

Scitovsky, Tibor. 1981. "The Desire for Excitement in Modern Society." Kyklos 34, no. 1: 3-13.

Shah, Sonali K., and Mary Tripsas. 2007. "The Accidental Entrepreneur: The Emergent and Collective Process of User Entrepreneurship." Strategic Entrepreneurship Journal 1, no. 1-2: 123-40.

Shane, Scott. 2003. A General Theory of Entrepreneurship: The IndividualOpportunity Nexus. Northampton, Mass.: Edward Elgar Publishing.

Vargo, Stephen L., and Robert F. Lusch. 2004. "Evolving to a New Dominant Logic for Marketing." Journal of Marketing 68, no. 1: 1-17.

Vargo, Stephen L., Paul P. Maglio, and Melissa Archupru Akaka. 2008. “On Value and Value Co-creation: A Service Systems and Service Logic Perspective." European Management Journal 26, no. 3: 145-52.

Witt, Ulrich. 2001. "Learning to Consume-a Theory of Wants and the Growth of Demand." Journal of Evolutionary Economics 11, no. 1: 23-36. 